University of Minnesota Morris Digital Well

University of Minnesota Morris Digital Well

\title{
Rock glaciers in central Colorado, U.S.A., as indicators of Holocene climate change
}

\author{
Kurt A. Refsnider \\ University of Wisconsin-Madison \\ Keith A. Brugger \\ University of Minnesota, Morris
}

Follow this and additional works at: https://digitalcommons.morris.umn.edu/geol_facpubs

Part of the Geology Commons, and the Glaciology Commons

\section{Recommended Citation}

Refsnider, K.A., and Brugger, K.A., 2007. Rock glaciers in Colorado, U.S.A., as indicators of late-Holocene climate change: a lichenometric study using Rhizocarpon subgenus rhizocarpon. Arctic, Antarctic, and Alpine Research, v. 39, 127-136.

This Article is brought to you for free and open access by the Faculty and Staff Scholarship at University of Minnesota Morris Digital Well. It has been accepted for inclusion in Geology Publications by an authorized administrator of University of Minnesota Morris Digital Well. For more information, please contact skulann@morris.umn.edu. 


\title{
ROCK GLACIERS IN CENTRAL COLORADO, U.S.A., AS INDICATORS OF HOLOCENE CLIMATE CHANGE
}

\author{
Kurt A. Refsnider* and Keith A. Brugger \\ Geology Discipline, University of Minnesota, Morris, 600 E. $4^{\text {th }}$ Street, Morris, Minnesota 56267, U.S.A. \\ *Present Address: University of Wisconsin - Madison, Department of Geology and Geophysics, 1215 W. \\ Dayton Street, Madison, WI 53706, U.S.A.
}

\begin{abstract}
We measured thalli diameters of the lichen Rhizocarpon subgenus Rhizocarpon on 48 individual lobes of 18 rock glaciers and rock glacier complexes in the Elk Mountains and Sawatch Range of central Colorado. Cumulative probability distribution and K-means clustering analyses were used to separate lichen thalli measurements into statistically-distinct groups, each interpreted as representing a discrete episode of rock glacier activity driven by an interval of cooler climate. Lichen ages for these episodes were assigned using a growth curve developed for Rhizocarpon geographicum in the nearby Front Range. An early Neoglacial episode, ca. $3080 \mathrm{yr} \mathrm{BP}$, is correlative to other glacial and periglacial activity in the southern Rocky Mountains and surrounding areas and broadly corresponds to an interval of climatic deterioration evident in several other proxies of Holocene climate. The younger two episodes, ca. 2070 and $1150 \mathrm{yr}$ BP, are also coeval with regional (Audubon) glacial and periglacial activity but are thus far not widely recognized in other climate proxies.
\end{abstract}

\section{INTRODUCTION}

Rock glaciers are lobate or tongue-shaped masses of rock and ice that form under cold climates in alpine regions and at high latitudes. Such climates promote the splitting of exposed bedrock in valley and cirque walls by frost action, and in some cases, the accumulation of interstitial ice in talus fields. In many alpine settings, rock glaciers are ubiquitous elements of the landscape and can contribute significantly to its geomorphic evolution by transporting large volumes of debris downslope by creep facilitated by ice deformation (Barsch, 1977; Giardino and Vitek, 1988; Humlum, 2000). Historically, two general models of 
rock glacier genesis have been proposed. One is a periglacial model (sensu Clark et al., 1998) wherein the in situ freezing of rain and melt water occurs within the interstices of pre-existing talus fields (Capps, 1910; Wahrhaftig and Cox, 1959; Outcalt and Benedict, 1965). The other is a glacigenic model in which an existing glacier is buried by rock debris. This debris is derived either from cliffs upslope or by the accumulation of debris melting out of the ice, subsequently insulating the underlying ice (Brown, 1925; Outcalt and Benedict, 1965; Potter, 1972). More recent work suggests these two models may represent end members of a continuous spectrum of the processes responsible for rock glacier development (Corte, 1987; Whalley and Martin, 1992; Elconin and LaChapelle, 1997; Brazier et al., 1998; Clark et al., 1998), but this conclusion is not universally accepted (e.g. Haeberli, 1985).

Regardless of their mode of formation, rock glaciers and/or rock glacier activity have been used in varying manners to reconstruct paleoclimates. Previous investigations (e.g. Birkeland, 1973; Miller, 1973; Morris, 1987; Nicholas and Butler, 1996) have used relict rock glaciers to simply establish qualitative chronologies of Holocene climate change because intervals of rock glacier activity often correlate chronostratigraphically with those of Neoglacial glacier expansion, thus broadly implying colder periglacial conditions. Several studies have used relict rock glaciers to derive more quantitative estimates of paleoclimate based on their implications for depression of snow- or equilibrium-line altitudes (ELAs), the lower limit of rock glaciers in relation to zones of continuous and discontinuous permafrost, or more specific relationships between modern climate and active rock glaciers (e.g. Kerschner, 1978; Clark et al., 1994; Brazier, et al., 1998; Sailer and Kerschner, 1999; Hughes et al., 2003). Rock glaciers do not, however, always show simple and consistent relationships to climatological parameters (Baroni et al., 2004), underscoring the need for a better understanding of the interactions between rock glaciers of a specific genetic origin (i.e., periglacial or glacigenic) and climate, debris supply, and topography (Olyphant, 1987; Kirkbride and Brazier, 1995; Humlum, 1998, 2000; Hughes et al., 2003) before their full potential as a climate proxy is realized. Nevertheless, some valuable insights regarding paleoclimates can be gleaned from rock glacier activity. In this study, we use lichenometry to date intervals of rock glacier activity to document late-Holocene climate changes in central Colorado. 


\section{METHODS}

\section{STUDY AREA}

The Sawatch Range (Figure 1) is a fault-bounded block consisting primarily of Precambrian crystalline rocks uplifted during the Late Mesozoic-Early Tertiary Laramide Orogeny (Tweto, 1987). In contrast, the Elk Mountains consist of thrust-faulted Paleozoic and Mesozoic sedimentary sequences. Tertiary intrusive rocks are common in both ranges. High peaks in the study area, many exceeding $4000 \mathrm{~m}$, are separated by deeply incised valleys or intermontane parks. The high relief of the region is the product of Tertiary uplift and stream dissection. Subsequent modification by successive Pleistocene glaciations created the present alpine landscape.

Climate across the study area is generally cool and dry but temperatures tend to decrease and precipitation increases from east to west. Differences in elevation notwithstanding, values for mean annual temperature and precipitation at Buena Vista $\left(2417 \mathrm{~m}\right.$; Figure 1) are $6.2^{\circ} \mathrm{C}$ and $25.5 \mathrm{~cm}$, whereas those at Crested Butte $(2706 \mathrm{~m})$ are $0.6^{\circ} \mathrm{C}$ and $60.6 \mathrm{~cm}$ (NCDC 1971-2000 norms from the Western Regional Climate Center, http://www.wrcc.dri.edu/summary/climsmco.html).

Within the study area, moraines of two late-Pleistocene glaciations are recognized in the Taylor Park area, adjacent parts of the Elk Mountains (Brugger and Goldstein, 1999; Brugger unpublished), and the upper Arkansas River valley (Figure 1, Nelson and Shroba, 1998). Cosmogenic ${ }^{10} \mathrm{Be}$ and ${ }^{36} \mathrm{Cl}$ zero-erosion exposure ages from boulders on last glacial maximum (LGM) terminal moraine complexes in the Taylor River valley (Figure 1) range from $16.3 \pm 1.6$ to $22.2 \pm 2.8$ ka (Brugger, 2006) and suggest glacial advances during the LGM in the study area are generally correlative to others in the Southern Rocky Mountain region (e.g. Gosse et al., 1995; Benson et al., 2005). ELA depression during the LGM suggests that mean summer temperatures in the region may have been $\sim 7-9^{\circ} \mathrm{C}$ cooler than present (Brugger and Goldstein, 1999; Brugger, 2006). Late glacial and Holocene climate changes that followed were described by both Fall (1997) and Emslie et al. (2005) and will be discussed subsequently.

\section{ROCK GLACIERS}

Rock glaciers are abundant within the study area. Many of these are relict features, or least inactive, as indicated by morphological characteristics including frontal slopes much less than the angle of repose, soil 
development and extensive vegetative cover, and/or stable and lichen-encrusted boulders. Others may still be active, as indicated by steep and sharp-crested fronts, "bull-dozed" turf rolls at the toes of frontal slopes, loose and unstable surface boulders above the toes, and a general lack of vegetation. Activity is also suggested by earlier measurements on two rock glaciers in the Elk Mountains (Bryant, 1971) and ongoing measurements on the East Beckwith rock glacier (Figure 2a; Brugger, unpublished) where mean velocities are 43,40 , and $7 \mathrm{~cm} \mathrm{yr}^{-1}$ respectively.

Morphologies and topographic settings of rock glaciers throughout the region vary. The majority of the rock glaciers we studied are located in cirque basins, and of these, approximately half are situated on slopes extending from the valley side rather than the headwall; those not in cirques are situated below rockwalls. Continuous talus deposits connect all the rock glaciers to the debris source cliffs above. Despite their location, those situated in cirques are mostly of the "valley-wall" type (Outcalt and Benedict, 1965). These rock glaciers are smaller lobate forms, often occurring below avalanche chutes and fed by talus slopes along sidewalls and typically extend onto basin floors but do not fill the entire basin. Brazier at al. (1998) recognized analogous, non-glacigenic forms in cirque basins of the Ben Ohau Range of New Zealand. The exceptions are several rock glaciers in the Beckwith Range and on Italian Mountain (Figure 1) that are best described as "cirque-floor" types. These larger tongue-shaped forms often fill the entire basin and emanate from talus slopes below cirque headwalls. However, these forms are not moraine-like deposits, nor do they have irregular surfaces associated with the stagnation of inactive, retreating debriscovered glaciers.

The rock glaciers in the study area include both single- (Figures 2a, lower left, and 2b) and multiplelobed forms (Figure 2c), where lobes are characterized as arcuate, steep-fronted features. Most multilobed forms exhibit stratigraphic relationships recording the advance of younger lobes over older ones (Figure 2c). The tongue-shaped rock glacier on East Beckwith Mountain shown in the center of Figure 2a is the only feature included in this study with prominent concentric lobes with ridge-like morphologies.

Without detailed geophysical studies (e.g. Potter et al., 1998; Ikeda and Matsuoka, 2002), glaciological approaches (e.g. Potter, 1972; Konrad et al., 1998), coring (Potter, 1972), or direct observations of their 
internal structure, it is difficult to be certain of the origin of the rock glaciers used in this study. However we suspect, as have others (e.g. Outcalt and Benedict, 1965; Calkin et al., 1987; Clark et al., 1994, 1998; Kirkbride and Brazier, 1995) that the morphology and topographic setting of the valley-wall rock glaciers (or equivalent forms) reflect a periglacial genesis. Such a presumption is supported by evidence suggesting that many cirque basins were ice-free prior to the rock glacier activity documented in this study (Fall, 1997). No evidence has been found suggesting that glaciers re-formed during Holocene cool intervals. In contrast, the cirque-floor rock glaciers in the Beckwith Range (Figure 2a, center) may be glacigenic. Within the largest of these rock glaciers, a discrete ice layer under the surface debris was evident in one exposure, and the ridge-like lobe-front morphology is possibly indicative of a glacigenic origin (Clark et al., 1998; Corte, 1987). Given the wetter and cooler climate in this part of the study area, glacial ice could have persisted (or re-formed) here longer than elsewhere in the study area.

\section{SAMPLING}

We selected 48 lobes on 18 rock glaciers or rock glacier complexes on the basis of location, elevation, and aspect. These rock glaciers fall within an east-west longitudinal transect $\left(106.15-107.22^{\circ} \mathrm{W}\right)$ and range in terminus elevation from 3,005 to $3,755 \mathrm{~m}$ (Table 1). Rock glacier surfaces were dated using lichenometry (Beschel, 1961; Noller and Locke, 2001), as in numerous other studies of Holocene landforms (e.g. Birkeland, 1973; Calkin et al., 1987; Morris, 1987; Nicholas and Butler, 1996; Konrad and Clark, 1998). The lichen Rhizocarpon subgenus Rhizocarpon (generally synonymous with Rhizocarpon geographicum in many lichenometric studies) was used because of its slow and steady growth in alpine and arctic regions, relative abundance at higher elevations on a variety of lithologies, and ease of identification (Noller and Locke, 2000).

We measured thalli diameters of lichens on distinct lobes at various elevations and positions within each rock glacier. Although there is no consensus regarding the most effective sampling strategy for determining the maximum lichen size on rock substrates (Innes, 1984; McCarrol, 1994; Bull and Brandon, 1998; Noller and Locke, 2000), we employed a sampling protocol similar to that used by Innes (1984) because it is most suitable for dating rock glacier deposits. The lichen distribution on each lobe was examined to locate the areas with the largest thalli. Once such areas were found, we established a circular 
sampling site with a radius of five meters. We sampled most lobes in two locations, and larger lobes and those with more variable lichen sizes were sampled in three areas. In nearly all cases, sampling sites were located just above the break in slope above the lobe terminus. Rock substrates were mostly of granitic lithologies, but some lichens were measured on gneissic and quartzitic boulders.

Within each sampling site, we measured the largest 25 Rhizocarpon subgenus Rhizocarpon thalli. These measurements were taken along the longest axis of each thallus, including the black prothallus rim. Lichens with very irregular shapes and those that appeared to have grown together were not measured. We avoided sampling in any areas that appeared to have suffered from snowkill, a phenomenon which can significantly affect the age distribution of lichens (Benedict, 1990, 1993).

\section{RESULTS}

Lichen thalli measured on rock glacier lobes varied in diameter from 28 to $260 \mathrm{~mm}$. Five of the largest of these, ranging in size from 160 to $260 \mathrm{~mm}$, were found on boulders greater than $4 \mathrm{~m}$ across occurring on a single lobe on the eastern flank of Italian Mountain. Hamilton and Whalley (1995) concluded that anomalously large thalli represent lichens that may have been established on rock substrates prior to deposition on the rock glacier. Therefore, following their suggestion, these larger lichens were excluded from subsequent statistical treatments of the data presented here. Three thalli on quartzite boulders from two lobes at Ferris Creek were between 168 and $190 \mathrm{~mm}$, but the size-frequency distribution of thalli on these lobes does not allow these larger thalli to be distinguished as statistical outliers.

Innes (1984) found the most accurate method for establishing maximum lichen size for a landform was to use the mean diameter of the largest five thalli from a sampling site. Using the five largest thalli from each lobe, the thalli size range becomes 39-190 mm (Figure 3a). For lobes where lichens were measured in multiple locations, we only used the largest mean in the data analysis.

The oldest lichens on an individual lobe were nearly always found just above the break in slope above the terminus. Lichens become smaller, and therefore younger, with increasing distance upslope. Generally, the differences between the mean diameter of the largest five lichens in several different sampling sites located across the front of a lobe were less than $10 \mathrm{~mm}$. Within a single rock glacier 
complex, such as those at East Beckwith East and Queen Basin (Figures 2a and c), nested and overlapping lobes exhibit older ages with increasing distance from the talus source. These observations support our assumption that each individual lobe represents a separate period of rock glacier activity.

\section{DISCUSSION}

\section{SIZE AND AGE DISTRIBUTIONS}

A local lichen growth curve has not yet been developed for the study area due to a lack of dated surfaces. Therefore, lichen ages in this study were calculated, as they have been elsewhere (e.g. Miller, 1973; Nicholas and Butler, 1996; Munroe, 2002), using a growth curve (Figure 3b) developed for Rhizocarpon geographicum in the Front Range of Colorado (Benedict, 1967). Revisions to this growth curve (Benedict, 1993) include the addition of a lichen with a thallus diameter of $131 \mathrm{~mm}$, so the curve now extends to nearly $4000 \mathrm{yr} \mathrm{BP}$ without extrapolation. We also recalibrated the ${ }^{14} \mathrm{C}$ age data used in this growth curve using CALIB 5.0.1 (Stuiver et al., 2005).

The applicability of Benedict's $(1967,1993)$ growth curve to the Elk Mountains and Sawatch Range warrants some additional discussion. Climate and substrate lithologies, with the exception of quartzitic boulders, in the study area are both very similar to those in the Front Range. Nonetheless differences in climate, though very minor, may affect lichen growth rates. Of note, Birkeland's (1973) earlier work in the Elk Mountains suggested that the growth rate for Rhizocarpon geographicum here could possibly be lower than that in the Front Range. In addition, there are conflicting conclusions regarding the influence of lithology (and associated textures) on lichen growth (cf. Bull and Brandon, 1998; Noller and Locke, 2000); i.e., growth rates of lichens on quartzitic substrates may differ from those on the granitic and gneissic rocks upon which Benedict's $(1967,1993)$ growth curve is based. Munroe (2002), in particular, concluded that the use of Benedict's $(1967,1993)$ curve could potentially underestimate lichen ages on quartzite. Lacking a more robust dataset to assess possible differences in growth rates on varied lithologies, only those lichen measurements from lobes comprised of granitic and gneissic boulders are emphasized in the analyses and conclusions that follow. 
We applied two different statistical methods to separate the lichen age-frequency data into statistically different groups: K-means clustering analysis and cumulative probability analysis (CPA). K-means clustering analysis separates a dataset into groups by maximizing between-group variation while minimizing within-group variation. Excluding measurements made on quartzitic boulders, this technique defined four groups (Figure 4a) with mean ages of 1136, 2149, 3031, and 3552 yr BP. A one-way ANOVA test confirmed that all four groups are significantly different at a $95 \%$ confidence level. Inclusion of the quartzitic boulder data does not significantly change these results, though the mean of the third-oldest peak becomes 219 yr older.

CPA sums the probability distributions of a dataset and incorporates normally-distributed errors. Using the ages of each of the five largest lichens on granitic and gneissic substrates from all lobes and an assigned common $1 \sigma$ uncertainty of 150 years (see below), three groups were identified with peak amplitude ages of 1178, 2012, and $3110 \mathrm{yr}$ BP (Figure 4b). These groups correspond very closely with the ages of the three youngest groups in the K-means clustering analysis. We note that including lichen measurements made on quartzite boulders in this analysis only has a sizeable affect on the oldest of group, increasing it to $3328 \mathrm{yr} \mathrm{BP}$ (Figure $4 \mathrm{~b}$ ). We repeated this analysis using the mean age of the largest five lichens from each rock glacier lobe, and again three very similar age groups were identified, with peak amplitude ages of 1132, 2044, and 3088 yr BP (Figure 4c). Inclusion of the measurements made on quartzite in this analysis changes the peak amplitude ages by between 72 and 136 years. Innes (1984) concluded that using the mean age of the largest five lichens provides the most accurate age of a landform, but our results suggest differences in age assignment using the largest five or the mean of the largest five thalli are minimal $(<4 \%)$.

For measurements made on granitic and gneissic boulders, three clusters of lichen ages for rock glacier surfaces are common to all three statistical analyses, having ages of approximately 1150, 2070, and 3080 yr BP. If lichen growth rates on quartzite are similar to those on granitic and gneissic substrates, rock glaciers surfaces cluster around ages of 1180, 2030, and $3270 \mathrm{yr} \mathrm{BP.} \mathrm{An} \mathrm{older} \mathrm{peak} \mathrm{in} \mathrm{the} \mathrm{K-means}$ clustering analysis (3550 yr BP, Figure 4a) was not differentiated by CPA. To varying degrees, all analyses 
reveal a subtle peak or "shoulder" between $2360-2540 \mathrm{yr}$ BP. This peak is not statistically significant, however, and therefore it and the $3550 \mathrm{yr}$ BP peak are not considered further in this paper.

The total uncertainty in the thallus diameter of each statistically-defined group is difficult to quantify. Uncertainties arising from sampling and the variability in the diameter of the largest five lichens on a specific lobe, as discussed above, are thought to be small $(<5 \%)$. Additional uncertainty arises from the method by which the data are segregated into groups. A Euclidian distance metric was used in the K-means clustering analysis, but other metrics result in only slightly different $(<1 \%)$ group mean ages. With due consideration of the greater uncertainties in the response time of rock glacier systems (Olyphant, 1987), lags in lichen colonization (probably fewer than 50 years; Beschel, 1961; Evans et al., 1999; Noller and Locke, 2000), and growth rates, a total uncertainty of 150 years is probably reasonable (cf. Kirkbride and Brazier, 1998). This uncertainty is most probably skewed toward older ages, making the assigned lichenometric ages minimum estimates.

\section{LICHENOMETRIC AGE SIGNIFICANCE AND PALEOCLIMATIC IMPLICATIONS}

It is generally accepted that the age of a rock glacier surface represents the time of debris production and deposition (Hamilton and Whalley, 1995; Kirkbride and Brazier, 1995; Konrad and Clark, 1998; Sloan and Dyke, 1998). Dated intervals of rock glacier activity are typically interpreted as periods of climate deterioration (e.g. Benedict, 1968; Birkeland, 1973; Miller, 1973; Calkin et al., 1987; Nicholas and Butler, 1996). However, few studies have explicitly considered the how the paleoclimatic interpretation of these ages might differ depending on the mode of rock glacier genesis. Morris (1987), Morris and Olyphant (1990), Brazier et al. (1998) and Hughes et al. (2003) stress that while rock glaciers of a periglacial origin likely indicate cooler temperatures, glacigenic rock glaciers may form under a warming climate. Given our assumption that most of the rock glaciers investigated in this study are periglacial in origin, we suggest that the lichen-dated surfaces documented here reflect rock glacier activity associated with intervals of cooler climate within the study area. Such conditions would not only promote the formation of interstitial ice, but also potentially increase debris supply by virtue of increased mechanical weathering by frost cracking (Walder and Hallet, 1986; Matsuoka, 2001; Hales and Roering, 2005). At some point, a combination of sufficient debris thickness and surface slope would generate the driving stress required for mobilization of 
the ice-rock mixture (Wahrhaftig and Cox, 1959; Kirkbride and Brazier, 1995). Rock glaciers remain active so long as driving stresses are sufficient and climate is such that interstitial ice could persist. In contrast, talus produced during warmer intervals would accumulate below rock walls, but because interstitial ice cannot form, new rock glaciers can neither develop nor can existing ones be reactivated.

The possibility exists, however, that rock glacier lobes were intermittently active during sustained periods of cooler climate (Kirkbride and Braizier, 1995). Rock glaciers might have become inactive as flow attenuated debris thicknesses and surface slopes and thus reduced driving stresses below some critical value. Continued debris accumulation might have eventually reactivated lobes as the threshold stress was restored. Under this scenario, rock glacier activity is not recording discrete intervals of cooling. Also, reactivation - caused by either increased talus deposition or a distinct cooling event - can result in a mantle of younger debris that buries older lobes or rock glacier surfaces. Consequently, Kirkbride and Brazier (1995) argue that (1) climate records derived from rock glacier activity may be incomplete, or complicated by non-climatically forced activity; (2) rock glaciers within individual basins may not show a coherent pattern of activity; and (3) regional climates signals deduced from rock glacier activity will necessarily be noisy.

Based on the foregoing, some caution should therefore be exercised when making climatic interpretations of rock glacier activity. However, we feel the lichen ages of 1150, 2070, and $3080 \mathrm{yr} B P$ date discrete intervals of debris delivery and transport to the front of individual rock glacier lobes under cooler climates. This conclusion is based on the statistically-significant clustering of lichen ages seen in Figure 4 and the close correlations between these ages and those of cool intervals inferred from other climate proxies documented elsewhere in the Rocky Mountain region. Independent of climate, the stochastic nature of rockfall, hence debris deposition on rock glacier surfaces, should preclude a clustering of lichen ages. Following Kirkbride and Brazier (1995), we note that even given the possibility of rockfalldriven "pulses" of rock glacier activity during prolonged cool intervals, it is unlikely that the latter persisted for 2000 years (ca. 3080 to $1150 \mathrm{yr}$ BP) during the late Holocene (see below). We suggest the greater frequency (or strength) evident in the youngest peak at $1150 \mathrm{yr}$ BP may be an artifact of the aforementioned burial of older rock glacier lobes by younger advances. Finally, it bears mentioning that if data from those 
few rock glaciers that may be of glacigenic origin is omitted from the foregoing analyses, the ages of individual peaks do not change significantly.

Episodes of rock glacier activity in the Sawatch Range and Elk Mountains are compared schematically with other proxy records of Holocene climate change in the southern Rocky Mountains and adjacent regions in Figure 5. Direct comparisons and/or correlations must necessarily be tentative due to: (1) the temporal resolution and age control of chronologies differ among individual studies; (2) having to recalibrate ${ }^{14} \mathrm{C}$ ages where necessary and possible (using CALIB 5.0.1, Stuiver et al., 2005); and (3) methodological and/or sampling differences (e.g. ages obtained using the largest versus the mean of the largest five lichens). Nonetheless, intervals of cooler climate inferred from rock glacier activity within the study area correspond with the broader regional pattern of mid- to late Holocene climate change.

Within the immediate study area, Fall (1997) used pollen spectra and plant macrofossils to reconstruct Holocene climates and found evidence indicating Neoglacial cooling beginning $4000{ }^{14} \mathrm{C}$ yr BP (ca. 4500 cal. yr BP) and lasting for perhaps 2000 years. Fall (1997) estimates mean annual temperatures during that interval decreased by $0.8^{\circ} \mathrm{C}$ (but were still $0.6-1.2^{\circ} \mathrm{C}$ warmer than modern climate), and conditions were drier from 4000 to $2600{ }^{14} \mathrm{C}$ yr BP (ca. 4500 to 2800 cal. yr BP). Winter precipitation may have dominated during this interval, implying that summers were very dry. By ca. $2000 \mathrm{yr} \mathrm{BP}$, the modern climate was established.

In the upper Gunnison Basin, plant material preserved in packrat middens also suggests a cooling period beginning $4000{ }^{14} \mathrm{C}$ yr BP and lasting until at least $3180{ }^{14} \mathrm{C}$ yr BP (ca. 4500 to $3500 \mathrm{cal}$. yr BP; Emslie et al., 2005). Pollen records from the San Juan Mountains in southwestern Colorado suggest cooling began by about $3500{ }^{14} \mathrm{C}$ yr BP (ca. 3780 cal. YR BP; Carrara et al., 1991). Analyses of fossil beetle assemblages in the Front Range of Colorado led Elias (1996) to conclude that a period with a gradual trend toward cooler summers was underway by 7800 yr BP but temperatures remained comparable to those today. However, between 2965 and $2680{ }^{14} \mathrm{C}$ yr BP (ca. 3150 and $2850 \mathrm{cal}$. yr BP), summer temperature could have been $1-2.5{ }^{\circ} \mathrm{C}$ cooler than present. Mean January temperatures throughout most of the Holocene are thought to have been below modern values until the last millennia (Elias, 1996). In the 
La Plata Mountains, mean July temperatures are inferred to have been cooler between 4000 and $2500{ }^{14} \mathrm{C}$ yr BP (ca. 4450 to 2880 cal. yr BP) on the basis of pollen spectra (Petersen and Mahringer, 1976). The oldest episode of rock glacier activity revealed by our study, occurring $\sim 3080 \mathrm{yr} \mathrm{BP}$, appears to be coeval with the earlier stages of the Neoglacial cooling documented by these studies. In addition, this episode coincides with widespread glacial or periglacial activity documented in the region, in particular the northern Sawatch Range (Miller, 1973), Front Range (Benedict, 1973, 1985), Sangre de Cristo Range (Morris, 1987; Armour et al., 2002), the La Sal Mountains (Nicholas and Butler, 1996), and the Uinta Mountains (Munroe, 2002).

The younger two episodes of rock glacier activity in the study area are correlative to Audubon-aged (Benedict, 1973, 1993) glacial deposits and rock glacier surfaces found throughout Colorado (Benedict, 1973, 1985; Birkleland, 1973; Miller, 1973; Morris, 1987) and Utah (Nicholas and Butler, 1996; Munroe, 2002). The cool intervals associated with these episodes are not apparent in other climate proxies, with the exception of a record of latewood frost-rings from the Front Range (Brunstein, 1996). These younger rock glacier surfaces also tend to occur in, although they are not exclusive to, the western portion of the study area (Table 1). We cannot say whether this is a result of more persistent rock glacier activity due to spatial trends in regional climate, differences in microclimates, more complete burial of older surfaces during younger advances, or simply due to sampling bias. Future work will focus on these questions by expanding the database and developing a local lichen growth curve.

\section{CONCLUSIONS}

Rock glacier surfaces and/or lobes of three discrete ages occur in the Sawatch Range and Elk Mountains, each representing an episode of increased debris production, formation of interstitial ice, and subsequent flow under cooler climates. The earliest episode, dated at $3080 \mathrm{yr} \mathrm{BP}$, is correlative with early Neoglacial glacial and periglacial activity elsewhere in the southern Rocky Mountains and adjacent areas and is closely associated with a cool interval identified in other climate proxies from the region. The younger two episodes, dated at 2070 and 1150 yr BP, also generally correspond to regional glacial and 
periglacial activity during the Audubon stade. As of yet however, these intervals have not been recognized in any other local climate proxies. This may suggest that these events are related to very local topoclimatic modification of regional- (or larger) scale climate forcings.

\section{ACKNOWLEDGEMENTS}

This research was made possible by the Research Experience for Undergraduates program at the Rocky Mountain Biological Laboratory in Gothic, Colorado (NSF grant DBI 9987953). Comments from Suzanne Anderson, Brian Whalley, and Jason Janke greatly improved the quality of this paper. Suggestions from Engin Sungar regarding statistical analyses were also very helpful.

\section{REFERENCES}

Armour, J., Fawcett, P.J., and Geissman, J.W., 2002: 15 k.y. Paleoclimatic and glacial record from northern New Mexico. Geology, 30: 723-726.

Baroni, C., Carton, A., and Seppi, R., 2004: Distribution and behavior of rock glaciers in AdamelloPresanella Massif (Italian Alps). Permafrost and Periglacial Processes, 15: 243-259.

Barsch, D., 1977: Nature and importance of mass-wasting by rock glaciers in alpine permafrost environments. Earth Surficial Processes, 2: 231-245.

Benedict, J.B., 1967: Recent glacial history of an alpine area in the Colorado Front Range, USA. I. Establishing a lichen growth curve. Journal of Glaciology, 6: 817-832.

Benedict, J.B., 1985: Arapaho Pass: Glacial geology and archeology at the crest of the Colorado Front Range. Research Report No. 3, Center for Mountain Archeology, Ward, Colorado. 197 p.

Benedict, J.B., 1990: Lichen mortality due to late-lying snow: results of a transplant study. Arctic and Alpine Research, 22: 81-91.

Benedict, J.B., 1993: A 2000-year lichen-snowkill chronology for the Colorado Front Range, U.S.A. The Holocene, 3: 27-33.

Benson, L., Madole, R., Landis, G., Gosse, J.C., 2005: New data for Late Pleistocene Pinedale alpine glaciation in southwestern Colorado. Quaternary Science Reviews, 24: 49-66.

Beschel, R., 1961: Dating rock surfaces by lichen growth and its application to glaciation and physiography (lichenometry). In Raasch, G.O. (ed.), Geology of the Arctic. Vol. 2. Toronto: University of Toronto Press, 1044-1062.

Birkeland, P.W., 1973: Use of relative age-dating methods in a stratigraphic study of rock glacier deposits, Mt. Sopris, Colorado. Arctic and Alpine Research, 5: 401-416.

Brazier, V., Kirkbirde, M.P., and Owens, I.F., 1998: The relationship between climate and rock glacier distribution in the Ben Ohau Range, New Zealand. Geografiska Annaler, 80A: 193-207.

Brown, W.H., 1925: A probable fossil glacier. Journal of Geology, 33: 464-66. 
Brugger, K.A., 2006: Late Pleistocene climate inferred from the reconstruction of the Taylor River Glacier Complex, southern Sawatch Range, Colorado. Geomorphology. (in press)

Brugger, K.A. and Goldstein, B.S., 1999: Paleoglacier reconstruction and late Pleistocene equilibrium-line altitudes, southern Sawatch Range, Colorado. In Mickelson, D.M. and Attig, I.W. (eds.), Glacial Processes Past and Present. Boulder, Colorado: Geological Society of America Special Paper 337: 103-112.

Brunstein, F.C., 1996: Climatic significance of the bristlecone pine latewood frost-ring record at Almagre Mountain, Colorado, U.S.A. Arctic and Alpine Research, 28: 65-76.

Bryant, B., 1971: Movement measurements on two rock glaciers in the eastern Elk Mountains, Colorado. U.S. Geology Survey Professional Paper 750-B: B108-B116.

Bull, W.B. and Brandon, M.T., 1998: Lichen dating of earthquake-generated regional rockfall events, Southern Alps, New Zealand. GSA Bulletin, 110: 60-84.

Calkin, P.E., Haworth, L.L., and Ellis, J.M., 1987: Rock glaciers of central Brooks Range, Alaska, U.S.A. In Giardino, J.R., Shroder, J.F., Jr., and Vitek, J.D. (eds.), Rock glaciers. London: Allen and Unwin, Inc., 65-82.

Capps, S.R., Jr., 1910: Rock glaciers in Alaska. Journal of Geology, 18: 359-375.

Carrara, P.E., Trimble, D.A., and Meyer, M., 1991: Holocene treeline fluctuations in the northern San Juan Mountains, Colorado, U.S.A., as indicated by radiocarbon-dated conifer wood. Arctic and Alpine Research, 23: 233-246.

Clark, D.H., Clark, M.M., and Gillespie, A.R., 1994: Debris-covered glaciers in the Sierra Nevada, California, and their implications for snowline reconstruction. Quaternary Research, 41: 139-153.

Clark, D.H., Steig, E.J., Potter, N., Jr., and Gillepsie, A.R., 1998: Genetic variability of rock glaciers. Geografiska Annaler, 80A: 175-182.

Corte, A.E., 1987: Rock glacier taxonomy. In Giardino, J.R., Shroder, J.F., Jr., and Vitek, J.D. (eds.), Rock glaciers. London: Allen and Unwin, Inc., 27-39.

Elconin, R.F. and LaChapelle, E.R., 1997: Flow and internal structure of a rock glacier. Journal of Glaciology, 43: 328-244.

Elias, S.A., 1996: Late Pleistocene and Holocene seasonal temperatures reconstructed from fossil beetle assemblages in the Rocky Mountains. Quaternary Research, 46: 311-318.

Emslie, S.D., Stiger, M., and Wambach, E., 2005: Packrat middens and late Holocene environmental change in southwestern Colorado. The Southwestern Naturalist, 50: 209-215.

Evans, D.J.A., Archer, S., and Wilson, D.J.H., 1999: A comparison of the lichenometric and Schmidt hammer dating techniques based on data from the proglacial areas of some Icelandic glaciers. Quaternary Science Reviews, 18: 13-41.

Fall, P.L., 1997: Timberline fluctuation and late Quaternary paleoclimates in the southern Rocky Mountains, Colorado. GSA Bulletin, 109: 1306-1320.

Giardino, J.R. and Vitek, J.D., 1988: The significance of rock glaciers in the glacial-periglacial landscape continuum. Journal of Quaternary Science, 3: 97-104.

Gosse, J.C., Klein, J., Evenson, E.B., Lawn, B., and Middleton, R., 1995: Beryllium-10 dating of the duration and retreat of the last Pinedale glacial sequence. Science, 268: 1329-1333.

Haeberli, W., 1985: Creep of mountain permafrost; internal structure and flow of alpine rock glaciers. Mitteilungen der Versuchsanstalt fuer Wasserbau, Hydrologie, und Glaziologie, 77: 142.

Hales, T.C. and Roering, J.J., 2005: Climate-controlled variations in scree production, Southern Alps, New Zealand. Geology, 33: 701-704. 
Hamilton, S.J. and Whalley, W.B., 1995: Preliminary results from the lichenometric study of the Nautardálur rock glacier, Tröllaskagi, northern Iceland. Geomorphology, 12: 123-132.

Hughes, P.D., Gibbard, P.L., and Woodward, J.C., 2003: Relict rock glaciers as indicators of Mediterranean paleoclimate during the Last Glacial Maximum (Late Würmian) in northwest Greece. Journal of Quaternary Science, 18: 431-440.

Humlum, O., 1998: The climatic significance of rock glaciers. Permafrost and Periglacial Processes, 9: 75395.

Humlum, O., 2000: The geomorphic significance of rock glaciers: estimates of rock glacier debris volumes and headwall recession rates in West Greenland. Geomorphology, 35: 41-67.

Ikeda, A. and Matsuoka, N., 2002: Degradation of talus-derived rock glaciers in the upper Engadin Valley, Swiss Alps. Permafrost and Periglacial Processes, 13: 145-161.

Innes, J.L., 1984: The optimal sample size in lichenometric studies. Arctic and Alpine Research, 16: 233244.

Kerschner, H. 1978: Paleoclimatic inferences from late Würm rock glaciers, eastern Central Alps, western Tyrol, Austria. Arctic and Alpine Research, 10: 635-644.

Kirkbride, M. and Brazier, V., 1995: On the sensitivity of Holocene talus-derived rock glaciers to climate change in the Ben Ohau Range, New Zealand. Journal of Quaternary Science, 10: 353-365.

Konrad, S.K. and Clark, D.H., 1998: Evidence for an early Neoglacial glacier advance from rock glaciers and Lake sediments in the Sierra Nevada, California, U.S.A. Arctic and Alpine Research. 30: 272-284.

Matsuoka, N. 2000: Direct observation of frost wedging in alpine bedrock. Earth Surface Processes and Landforms, 26: 601-614.

McCarroll, D., 1994: A new approach to lichenometry: dating single-age species and diachronous surfaces. The Holocene, 4: 383-396.

Miller, C.D., 1973: Chronology of Neoglacial deposits in the northern Sawatch Range, Colorado. Arctic and Alpine Research, 5: 385-400.

Morris, S.E., 1987: Regional and topoclimatic implications of rock glacier stratigraphy: Blanca Massif, Colorado in Giardino, J.R., Shroder, J.F., Jr., and Vitek, J.D. (eds.), Rock glaciers. London: Allen and Unwin, Inc., 107-125.

Morris, S.E. and Olyphant, G.A., 1990: Alpine lithofacies variations: working toward a physically-based model. Geomorphology, 3: 73-90.

Munroe, J.S., 2002: Timing of postglacial cirque reoccupation in the northern Uinta Mountains, northeastern Utah, U.S.A. Arctic, Antarctic, and Alpine Research, 34: 38-48.

Nelson A.R. and Shroba, R.R., 1998: Soil relative dating of moraine and outwash-terrace sequences in the northern part of the upper Arkansas Valley, central Colorado. Arctic and Alpine Research, 30: 349-361.

Nicholas, J.W. and Butler, D.R., 1996: Application of relative-age dating techniques on rock glaciers of the La Sal Mountains, Utah: an interpretation of Holocene paleoclimates. Geografiska Annaler, 78: 1-18.

Noller, J.S. and Locke, W.W., 2000: Lichenometry in Noller, J.S., Sowers, J.M., and Lettis, W.R. (eds.), Quaternary Geochronology Methods and Applications. Washington D.C.: American Geophysical Union, 261-272.

Olyphant, G.A., 1987: Rock glacier response to abrupt changes in talus production in Rock glaciers in Giardino, J.R., Shroder, J.F., Jr., and Vitek, J.D. (eds.), Rock glaciers. London: Allen and Unwin, Inc., 355.

Outcalt, S.I. and Benedict, J.B., 1965: Photo-interpretation of two types of rock glaciers in the Colorado Front Range, U.S.A. Journal of Glaciology, 5: 849-856. 
Petersen, K.L. and Mehringer, P.J., 1976: Postglacial timberline fluctuations, La Plata Mountains, southwestern Colorado. Arctic and Alpine Research, 8: 275-288.

Potter, N., Jr., 1972: Ice-cored rock glacier, Galena Creek, northern Absoroka Mountains, Wyoming. Geological Society of America Bulletin, 83: 3025-3058.

Potter, N., Steig, E.J., Clark, D.H., Speece, M.A., Clark, G.M., and Updike, A.B., 1998: Galena Creek rock glacier revisited - new observations on an old controversy. Geografiska Annaler, 80A: 251-265.

Sailer, R. and Kerschner, H. 1999: Equilibrium-line altitudes and rock glaciers during the Younger Dryas cooling event, Ferwell group, western Tyrol, Austria. Annals of Glaciology, 28: 141-145.

Sloan, V.F. and Dyke, L.D., 1998: Decadal and millennium velocities of rock glaciers, Selwyn Mountains, Canada. Geografiska Annaler, 80A: 237-249.

Stuiver, M., Reimer, P.J., and Reimer, R.W., 2005: CALIB 4.3 [WWW program and documentation]. Seattle: University of Washington and Belfast: Queen's University of Belfast. URL: <www.calib.org>.

Tweto, O., 1987: Rock units of the Precambrian basement in Colorado. U.S. Geol. Surv. Prof. Paper 1321A.

Walder, J.S. and Hallet, B., 1986: The physical basis of frost weathering: toward a more fundamental and unified perspective. Arctic and Alpine Research, 18: 27-32.

Whalley, W.B. and Martin, H.E., 1992: Rock glaciers: II models and mechanisms. Progress in Physical Geography, 16: 127-186.

Wharhaftig, C. and Cox, A., 1959: Rock glaciers in the Alaska Range. Geological Society of America Bulletin, 70: 383-436. 
TABLE 1. Site and lichen data from each rock glacier lobe included in this study

\begin{tabular}{|c|c|c|c|c|c|c|c|c|c|}
\hline Location & $\begin{array}{l}\text { Latitude } \\
{ }^{\circ} \mathrm{N}\end{array}$ & $\begin{array}{l}\text { Longitude } \\
{ }^{W}\end{array}$ & $\begin{array}{c}\text { Elev. } \\
\text { m }\end{array}$ & $\begin{array}{c}\text { Slope, } \\
\text { deg. }\end{array}$ & Aspect & Lithology & $\begin{array}{c}\text { Thallus } \\
\text { Size, } \mathrm{mm}^{*}\end{array}$ & $\begin{array}{c}\text { St. Dev. } \\
\text { mm }\end{array}$ & $\begin{array}{c}\text { Age } \\
\text { years BP }\end{array}$ \\
\hline East Beckwith Central & 38.8546 & 107.2238 & 3333 & 46 & NW & Granitic & 53 & 2 & 1202 \\
\hline East Beckwith Central & 38.8581 & 107.2211 & 3195 & 41 & NW & Granitic & 48 & 3 & 1038 \\
\hline East Beckwith East & 38.8444 & 107.2185 & 3544 & 30 & $\mathrm{~N}$ & Granitic & 44 & 3 & 907 \\
\hline East Beckwith East & 38.8448 & 107.2159 & 3533 & 35 & NNW & Granitic & 46 & 4 & 973 \\
\hline East Beckwith East & 38.8462 & 107.2150 & 3492 & 37 & $\mathrm{~N}$ & Granitic & 58 & 5 & 1365 \\
\hline East Beckwith East & 38.8475 & 107.2144 & 3435 & 22 & $\mathrm{~N}$ & Granitic & 57 & 5 & 1332 \\
\hline East Beckwith East & 38.8483 & 107.2142 & 3414 & 46 & $\mathrm{~N}$ & Granitic & 54 & 1 & 1234 \\
\hline East Beckwith East & 38.8499 & 107.2105 & 3428 & 30 & NW & Granitic & 53 & 4 & 1202 \\
\hline East Beckwith East & 38.8528 & 107.2094 & 3362 & 28 & NNW & Granitic & 53 & 2 & 1202 \\
\hline East Beckwith East & 38.8569 & 107.2092 & 3147 & 34 & NW & Granitic & 50 & 2 & 1104 \\
\hline East Beckwith East & 38.8582 & 107.2084 & 3093 & 31 & NW & Granitic & 55 & 4 & 1267 \\
\hline Gothic Mountain & 38.8595 & 107.0091 & 3567 & 38 & $\mathrm{NE}$ & Granitic & 61 & 11 & 1463 \\
\hline Virginia Basin & 38.9727 & 106.9788 & 3332 & 36 & WSW & Quartzitic & 118 & 10 & 3325 \\
\hline Virginia Basin & 38.9726 & 106.8624 & 3313 & 34 & Wsw & Quartzitic & 76 & 4 & 1953 \\
\hline Copper Creek & 38.9613 & 106.9701 & 3048 & 32 & NW & Granitic & 50 & 3 & 1104 \\
\hline Copper Creek & 38.9609 & 106.9693 & 3054 & 42 & NNW & Granitic & 42 & 2 & 842 \\
\hline Copper Creek & 38.9598 & 106.9684 & 3109 & 26 & W & Granitic & 41 & 1 & 809 \\
\hline Copper Creek & 38.9596 & 106.9670 & 3161 & 40 & NW & Granitic & 43 & 5 & 875 \\
\hline Queen Basin & 38.9750 & 106.9430 & 3482 & 37 & sW & Granitic & 79 & 2 & 2051 \\
\hline Queen Basin & 38.9747 & 106.9407 & 3539 & 38 & sw & Granitic & 89 & 3 & 2378 \\
\hline Queen Basin & 38.9760 & 106.9384 & 3574 & 36 & WSW & Granitic & 61 & 4 & 1463 \\
\hline Queen Basin & 38.9762 & 106.9357 & 3644 & 43 & WSW & Granitic & 72 & 6 & 1822 \\
\hline Queen Basin & 38.9763 & 106.9328 & 3722 & 46 & W & Granitic & 51 & 9 & 1136 \\
\hline Queen Basin & 38.9763 & 106.9328 & 3723 & 48 & W & Granitic & 49 & 4 & 1071 \\
\hline Ferris Creek & 38.8519 & 106.8848 & 3005 & 40 & W & Quartzitic & 142 & 17 & 4109 \\
\hline Ferris Creek & 38.8518 & 106.8823 & 3053 & 25 & NW & Quartzitic & 119 & 11 & 3358 \\
\hline Ferris Creek & 38.8504 & 106.8804 & 3086 & 31 & NW & Quartzitic & 167 & 14 & 4925 \\
\hline Ferris Creek & 38.8567 & 106.8624 & 3061 & 32 & WSW & Quartzitic & 131 & 7 & 3750 \\
\hline Ferris Creek & 38.8548 & 106.8523 & 3336 & 26 & NNE & Quartzitic & 130 & 25 & 3717 \\
\hline Ferris Creek & 38.8548 & 106.8523 & 3330 & 32 & NNE & Quartzitic & 123 & 3 & 3488 \\
\hline Ferris Creek & 38.8382 & 106.8520 & 3293 & 28 & NNE & Quartzitic & 75 & 5 & 1920 \\
\hline Italian Mountain & 38.9511 & 106.7457 & 3661 & 45 & $\mathrm{NE}$ & Granitic & $205^{\dagger}$ & 41 & 6167 \\
\hline Italian Mountain & 38.9519 & 106.7444 & 3644 & 36 & $\mathrm{NE}$ & Granitic & 86 & 6 & 2280 \\
\hline Italian Mountain & 38.9527 & 106.7431 & 3607 & 37 & NNE & Granitic & 80 & 8 & 2084 \\
\hline Pieplant Creek & 38.9559 & 106.5473 & 3519 & 41 & $\mathrm{~s}$ & Granitic & 92 & 3 & 2476 \\
\hline Pieplant Creek & 38.9559 & 106.5473 & 3519 & 41 & $s$ & Granitic & 82 & 7 & 2149 \\
\hline Cumberland Pass & 38.6930 & 106.4696 & 3566 & 32 & SE & Granitic & 91 & 8 & 2443 \\
\hline Cumberland Pass & 38.6925 & 106.4689 & 3560 & 39 & SE & Granitic & 101 & 7 & 2770 \\
\hline Cumberland Pass & 38.6909 & 106.4616 & 3572 & 36 & SE & Granitic & 109 & 14 & 3031 \\
\hline Cumberland Pass & 38.6911 & 106.4610 & 3572 & 22 & SE & Granitic & 109 & 13 & 3031 \\
\hline Cottonwood Pass & 38.8178 & 106.4011 & 3541 & 31 & SSE & Gneissic & 121 & 12 & 3423 \\
\hline Cottonwood Pass & 38.8029 & 106.3852 & 3340 & 36 & NNW & Gneissic & 115 & 5 & 3227 \\
\hline Cottonwood Pass & 38.8016 & 106.3841 & 3336 & 36 & $\mathrm{~N}$ & Gneissic & 129 & 15 & 3684 \\
\hline Cottonwood Pass & 38.7990 & 106.3819 & 3385 & 39 & $N E$ & Gneissic & 113 & 13 & 3162 \\
\hline Mount Democrat & 39.3237 & 106.1614 & 3755 & 41 & NW & Granitic & 75 & 3 & 1920 \\
\hline Mount Democrat & 39.3261 & 106.1595 & 3729 & 39 & NW & Granitic & 108 & 3 & 2998 \\
\hline Mount Democrat & 39.3296 & 106.1562 & 3659 & 42 & NW & Granitic & 76 & 5 & 1953 \\
\hline Mount Democrat & 39.3304 & 106.1549 & 3639 & 47 & NNW & Granitic & 79 & 1 & 2051 \\
\hline
\end{tabular}

Mean of the largest five thalli on each lobe

† Data considered statistical outliers and are excluded from statistical analyses 


\section{FIGURE CAPTIONS}

FIGURE 1. LANDSAT 7 (grayscale) image of the study area showing the locations of rock glaciers sampled. The first number corresponds to the following: 1 - Gothic Mountain; 2 - Virginia Basin; 3 - Copper Creek; 4 - Queen Basin; 5 - East Beckwith Mountain; 6 - Ferris Creek; 7 - Italian Mountain; 8 - Pieplant Creek; 9 - Cottonwood Pass; 10 - Cumberland Pass; and 11 - Mount Democrat. The second number indicates the number of individual lobes upon which lichen measurements were made at each location.

FIGURE 2. Examples of sampling locations (open circles) and lobe (lines) ages on several rock glaciers and rock glacier complexes; numbers indicate the deposit age at each sampling location. Note the general increase in deposit age with increasing distance from the talus source. (a) Rock glaciers in the northeastern cirque of East Beckwith Mountain. (b) A series of rock glaciers in the cirque immediately east of Mount Democrat. (c) The rock glacier complex in Queen Basin.

FIGURE 3. (a) Size-frequency distribution for lichen thalli diameters on rock glacier surfaces. A distinction is made between the distribution resulting from measurements made exclusively on granitic and gneissic substrates and those including measurements made on quartzitic substrates because growth rates on the latter may differ. Inset (b) shows the growth curve used to calculate the age of the peaks in the sizefrequency plot (after Benedict, 1993). The linear regression $\left(r^{2}=0.985\right)$ is valid for thalli greater than $20 \mathrm{~mm}$ on the long axis; lichen growth rate is $\sim 0.031 \mathrm{~mm} \mathrm{yr}^{-1}$. The ages of radiocarbon-dated surfaces have been recalibrated using CALIB 5.0.1 (Stuvier et al., 2005). Error bars indicate $1 \sigma$ uncertainty in the radiocarbon ages.

FIGURE 4. Frequency distribution and clustering of rock glacier ages. (a) K-means clustering analysis. Each peak on the curve is statistically-distinct at a 95\% confidence level. (b) Cumulative probability Gaussian distributions based on the largest five lichen thalli from each lobe and an assigned uncertainty $(1 \sigma)$ of 150 years in each age. (c) Cumulative probability Gaussian distributions based on the mean of the largest five thalli from each lobe, also using an assigned uncertainty $(1 \sigma)$ of 150 years. The histograms in (b) and (c) differ because (b) is based on 5 times more data points than (c).

FIGURE 5. Comparison of intervals of rock glacier activity determined from this study (vertical bars) with selected paleoclimate proxies (horizontal bars) in the southern Rocky Mountains and surrounding areas. The approximate locations of the latter are shown in the inset map. Cool intervals (darker gray) are variously defined in these studies as cooler than present, cooler than some long-term mean, cooler mean annual temperatures, cooler summer temperatures, and so forth. See text for discussion. 


\section{FIGURE 1}

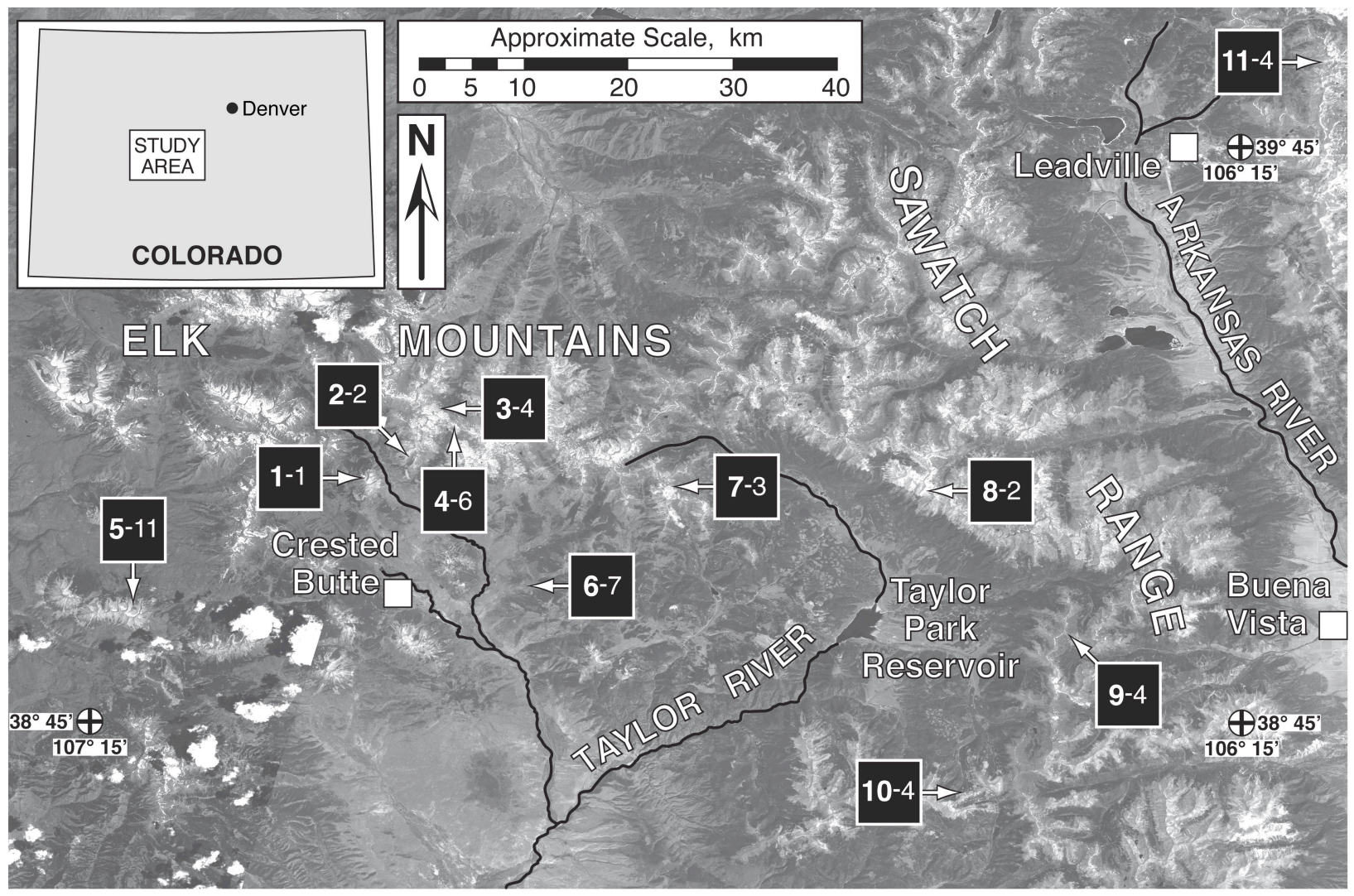




\section{FIGURE 2}
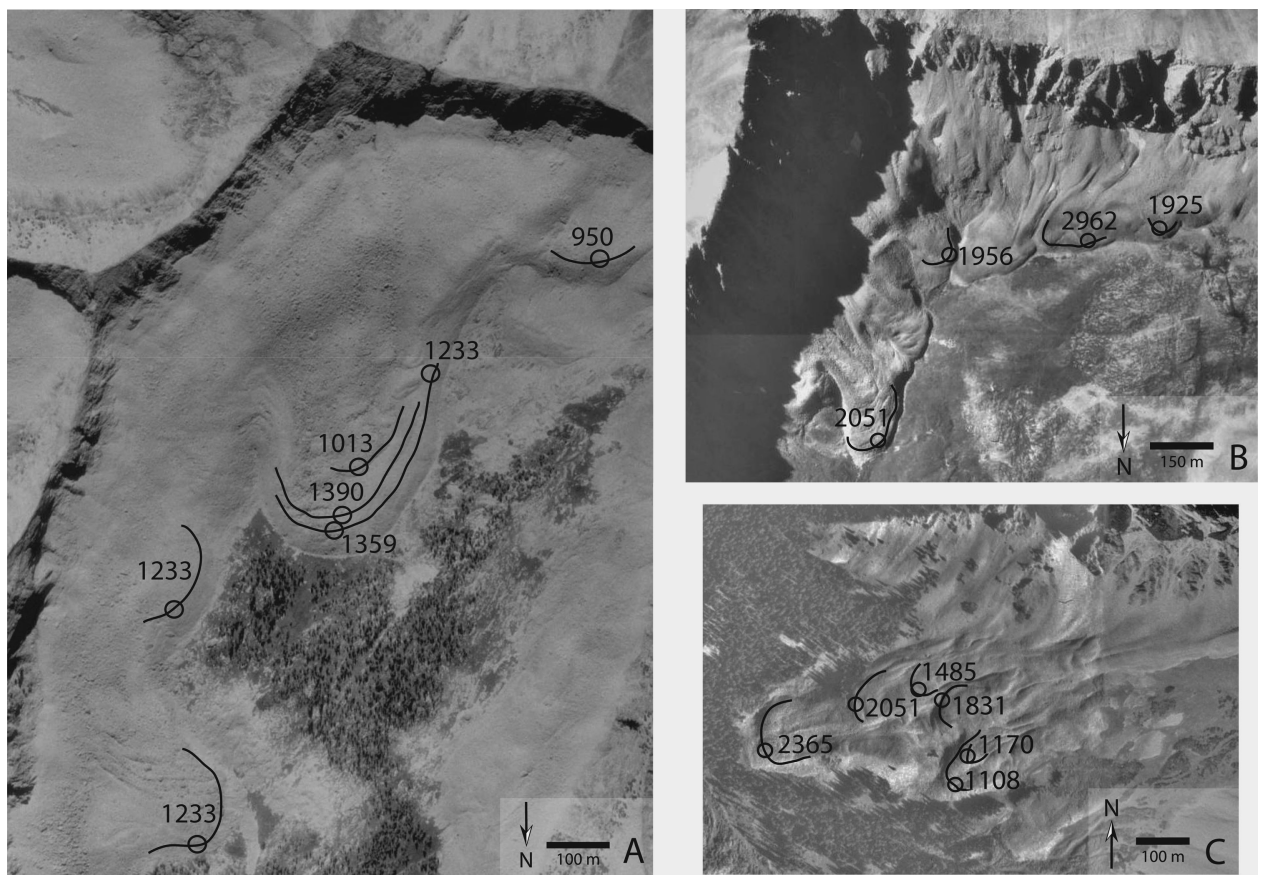


\section{FIGURE 3}

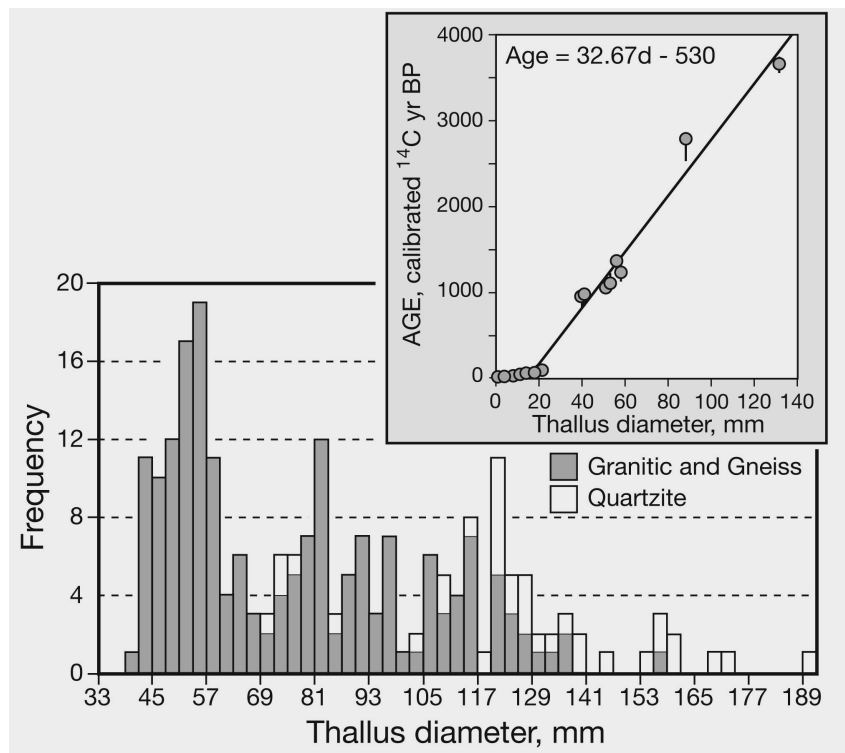




\section{FIGURE 4}
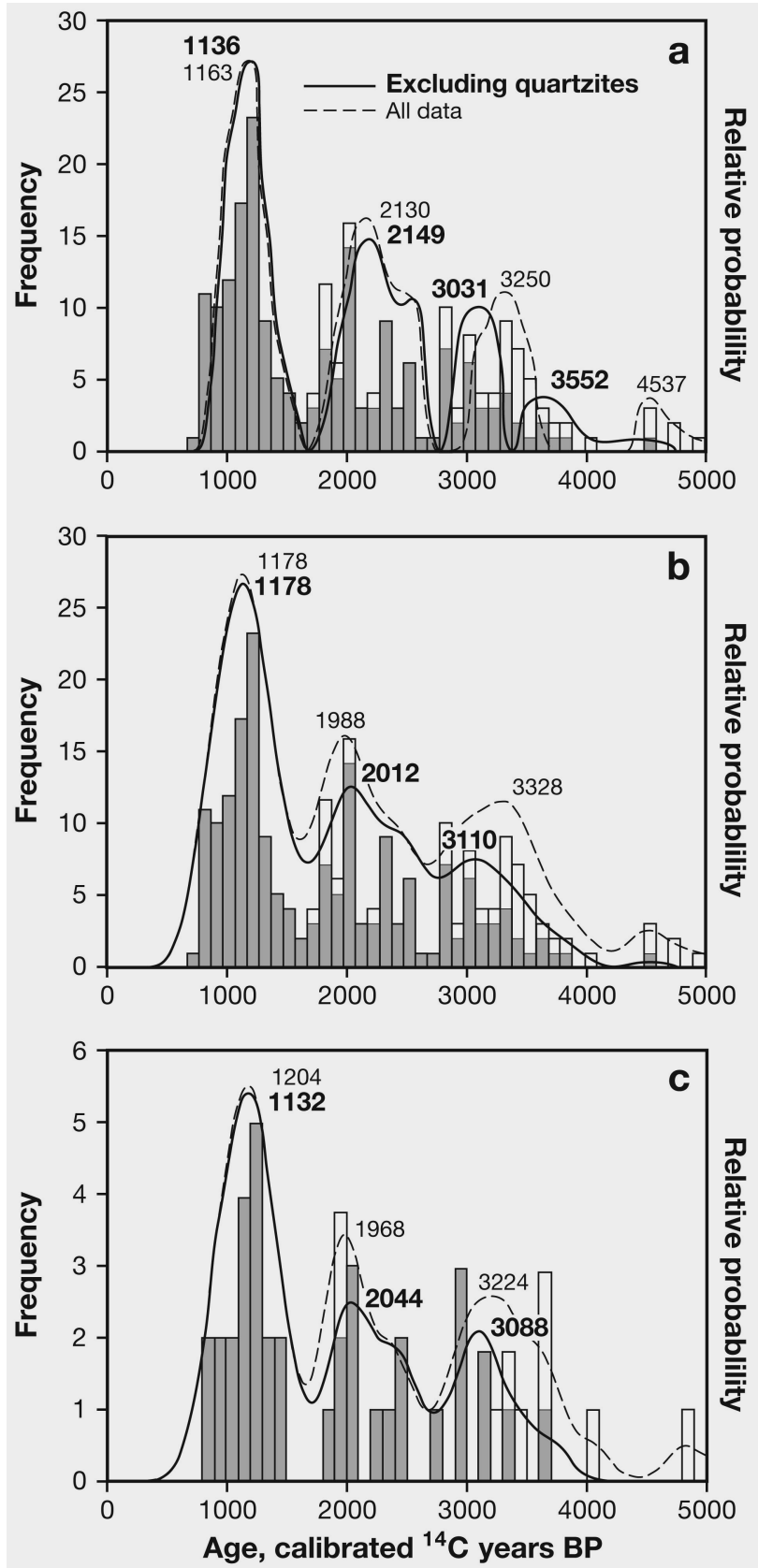


\section{FIGURE 5}

\section{LOCATION}

(Reference)

(1) Front Range, Colorado (Benedict, 1967, 1985, 1993)

(2) Elk Mountains,

Colorado

(Birkeland, 1973)

(3) N. Sawatch Range, Colorado (Miller, 1973)

(4) Sangre de Cristo Mts, Colorado (Morris, 1987)

(5) La Sal Mts, Utah (Nicholas and Butler, 1996)

(6) Sangre de Cristo Mts, New Mexico (Armour, et al. 2002)

(7) Uinta Mts, Utah (Munroe, 2002)

(8) Elk Mts and Sawatch Range, Colorado (Fall, 1997)

(9) Gunnison Basin, Colorado (Emslie et al., 2005)

(10) La Plata Mts, Colorado (Petersen and Mehringer, 1976)

(11) Front Range, Colorado (Elias, 1996)

(12) San Juan Mts, Colorado (Carrara et al., 1991)

(13) Front Range, Colorado (Brunstein, 1996)

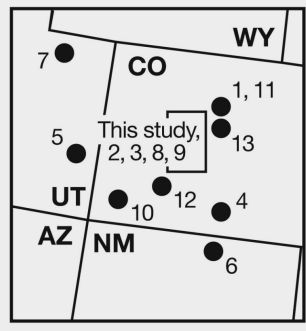

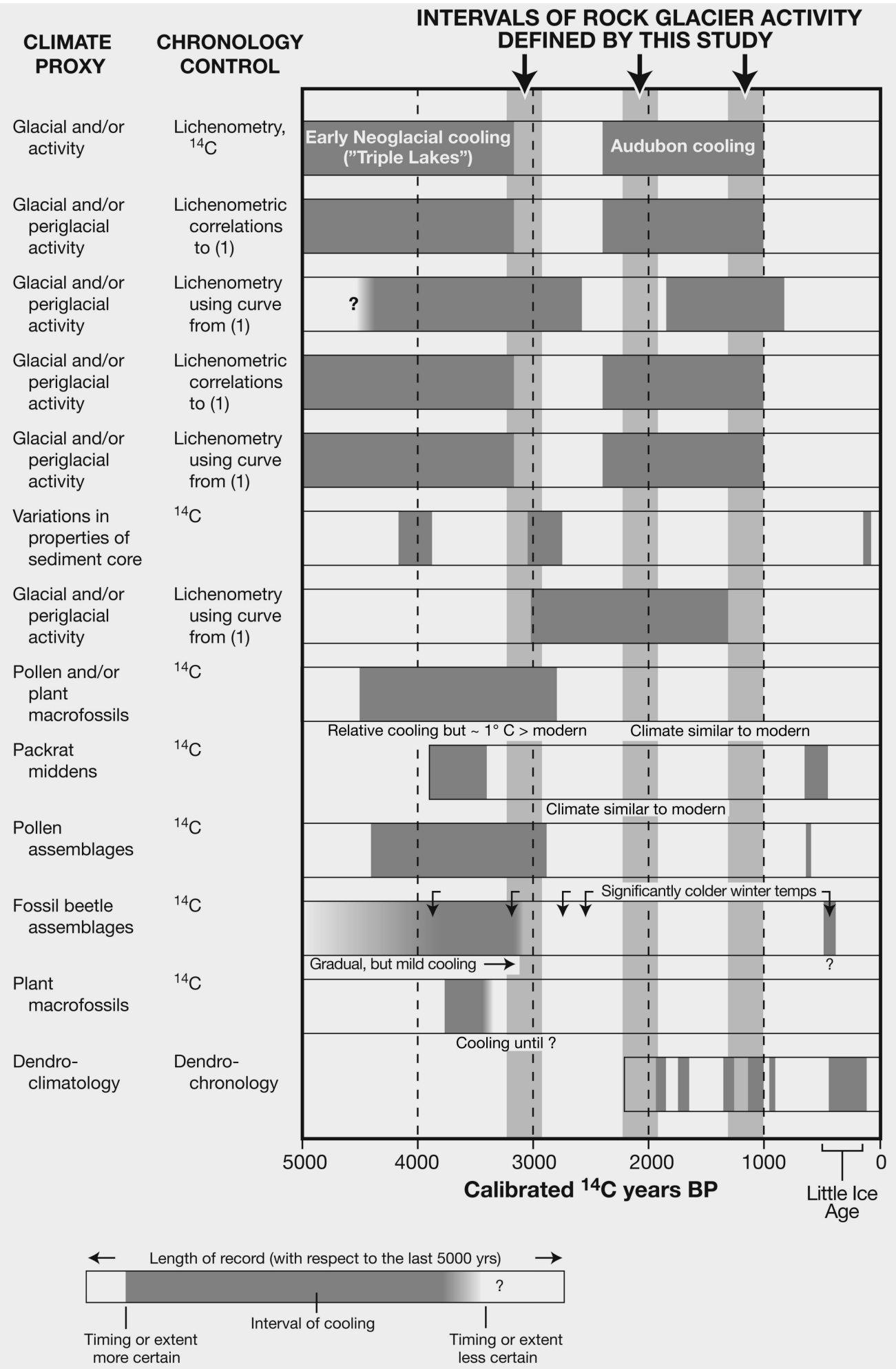

